\title{
The Military and Socio-Economic Development in Nigeria (1983 - 1999). A Critical Appraisal
}

\author{
Patrick Oluseun Bamgboye, PhD \\ Department of Sociology and Anthropology, University of Uyo, \\ Uyo Akwa Ibom State, Nigeria
}

Doi:10.5901/mjss.2014.v5n23p2340

Abstract

The paper appraises the role of the military in the socio-economic development of Nigeria. The paper observes that within the period of military regimes in Nigeria, several policies and programmes were initiated and implemented towards the socioeconomic development of the country but with little or no positive impact on the socio-economic development of the citizens of the country. The paper recommends Inter alia that the professionalization and increase budgetary allocation to the Nigeria military would not only encourage them to concentrate on their primary constitutional role but would also dissuade them from intervening in politics, thereby allowing the governance of the country to civilians who are supposed to be better placed to initiate and implement policies and programmes for the socio-economic development of the country.

Keywords: Military, Military regime, Socio-economic Development

\section{Introduction}

Nigeria chequered history is characterized by prolonged years of military regimes as opposed to democratic government. Out of the country's 54 years of independence, 29 have been spent under military regimes as against 25 years under civilian governments (Eminue; 2006).

It should however be noted that the country over the years, has had to grapple with the daunting task of development. Unfortunately various human development indexes still rank Nigeria among the poorest countries of the world interms of socio-economic development (Eshikena; 2012).

Nonetheless, Eminue (2003) and Adesina (1999), observed that one major justification for past military intervention in governance is the mismanagement of the country's resources by civilian governments which in turn has led to poor socio-economic development of the citizenry, while the military described themselves as "Corrective regimes" (Eshikena, 2012). This is done as a way of legitimizing their stay in power.

A critical look at the programmes and policies of successive military regimes in Nigeria shows that they have made varying impact on the nation's socio-economic development. It is therefore pertinent to assess the impact of the military in the socio-economic development of Nigeria, hence, this appraisal.

\section{Conceptual Issues}

We shall define the following concept as they relate to this study.

- The Military: The military is generally and popularly conceived as the "totality of the armed forces found the world over, which include the army, navy, air force and to some extent the police" (Oyediran, 1996).

- Military Regime: Eshikena (2012), defines military regime as a government led by military leaders. But it is generally regarded as an aberration of governance and a negation of political development.

Eminue (2006), sees military regime as governance dominated by military leaders. This is in line with Joseph (1991) view, that it is when the military expand their barracks' boundaries to the governance boundaries. Elaigwu (2000), on the other hand argues that the military has become a political power contestant in Nigeria's power equation, that must be "de-politicized". This is to say that the military is a politicized institution, indulging more in governance than their conventional role in Nigeria. 


\section{Socio-Economic Development}

Ekele (2011) defines socio-economic development as an inter-face of social and economic development of people, with emphasis on human capital development, poverty alleviation, employment generation and general economic development.

WiseGeek (2014) conceptualizes socio-economic development as a process that seeks to highlight the social and economic needs of the people, in more practical and utilitarian terms, as well as on a long run. WiseGeek argues further that the general idea of socio-economic development, is on improved standard of living, healthy economy capable of sustaining the population.

\section{Theoretical Issues}

Socio-economic Development Hypothesis: Samuel Finer's (1981) socio-economic Development hypothesis posits that "the propensity for military intervention is likely to increase with increased social mobilization, with grave implication on socio-economic development. In his contribution, Karl Deutsch (1961) argues, the social mobilization entails "old social, economic and psychological commitments which are eroded or broken and people available for new patterns of socialization and behaviour".

The social mobilization is said to generate pressures which cannot be sustained and the needs that can barely be met, as the "revolution of rising expectation" results to revolution of increasing frustrations and unfulfilled expectations. This offers a measure of explanation to some reasons given by the military for intervening in politics. In contradiction, the failure to handle the social mobilization properly by the military also led to agitations for their exit from power (Eminue, 2006). The challenge of socio-economic development of the country has been seriously undermined by successive military regimes as against the high hopes of Nigerians at the dawn of independence. The drawbacks in an attempt to meet the high expectations, in terms of socio-economic development of the country has often led to reoccurring social mobilization for the military to exit power.

\section{The Push Theory}

Janowitz (1964) stresses the fact that military organization is unstatic but dynamic, which changes over time and respond to chaning conditions and needs. He identified certain internal characteristics such as "the social background of the officers, the skill structure and career lines, internal social cohesion and cleavages, political ideology, strict discipline as factors that can push the military to intervene in politics.

\section{The Elite - Mass Gap Thesis}

Mazrui (1975), identifies the character of the ruling elite that emerged at the dawn of independence as the source of instability in the new states of Africa. These ruling elites did not meet the expectations of their citizenry interms of socioeconomic development of their countries. The socio-economic transformation has become a mirage as poverty, hunger, disease, insecurity, corruption and mismanagement of resources prevailed. Consequent upon the scenario, the military must have thought they could bridge the gap with their policies and programmes but the reverse was the case as very little achievements were recorded during military regimes in terms of socio-economic development.

\section{Historical Overview to Military Regime In Nigeria}

As earlier stated, Nigeria history is replete with several military regimes. Each regime remain unique and their stay in power varies due to circumstances surrounding their incursion into politics.

Eshikena (2012) observes that the first incursion of military in governance in Nigeria was in January, 1966. This ushered in the General Aguiyi Ironsi regime. The regime attempted to make sweeping constitutional changes, especially the initiative of a unitary government as against the federal system that was hither to practiced. The regime was however short lived.

In July 15, 1966, a counter-coup struck, sweeping away the Ironsi regime. This brought about the regime of Lt. Colonal Yakubu Gowon, a regime that continued to play politics with its exit from power until it was toppled nine (9) years later. The coup that ousted the Gowon regime brought about General Murtala Mohammed regime on July, 1975. General Murtala Muhammed regime was brought to an abrupt end when he was killed in an aborted coup led by Lt. Colonel 
Dimka on February 13th 1976 . This paved the way for his chief of staff, major General Olusegun Obasanjo as Head of State. The latter made frantic efforts to complete the transition programme to civil rule initiated under the regime of General Murtala Mohammed.

The Obasanjo regime handed over power to the civilian regime of Alhaji Shehu Shagari on October $1^{\text {st }}, 1979$ (Eshikana, 2012). The civilian government of Shehu Shagari was over thrown by a coup that brought major General Muhammadu Buhari to power on December $31^{\text {st }}, 1983$. The Buhari regime was ousted in a palace coup master minded by his chief of army staff in person of General Ibrahim Babangida on 27 $7^{\text {th }}$ of August, 1985.

The Babangida regime came up with a contrived and prolonged transition programme that affected the political development of Nigeria in no small measure, this regime lasted for 8 years, and due to the political crisis that engulfed the nation as a result of the administration's annulment of the celebrated June 12, 1993, presidential election won by chief Moshood Abiola, the Babangida's regime bowed to mounting pressure that resulted into the handing over power to a contrived interim National Government headed by Chief Earnest Shonekan on 26 th of August, 1993.

The Chief Earnest Shonekan regime was toppled in a bloodless coup that brought General Sanni Abacha to power on November, 17th, 1993. the Abacha regime's manipulated transition programme did not see the light of day as he suddenly died in office after 5 years in power. This scenario brought General Abdusalami Abubakar to power on $9^{\text {th }}$ June, 1998. the regime carried out the shortest transition programme to civil rule in Africa ever, by handing over power to the civilian government of Chief Olusegun Obasanjo on May 29, 1999.

\section{An Appraisal of the Military and Socio-Economic Development in Nigeria}

Both Eminue (2002) and Ekele (2011) argued that the Nigeria military has had a profound effect on the socio-economic development of the country. The contention here is that their policies, programmes and actions have created a measure of impact on Nigeria's socio-economic development on many issues and in different sectors of the economy. Some of such policies and programmes according to Elaigwu. (1979), Ekele (2011) and Eminue (2002) have profoundly shaped the foundation of the country's socio-economic development still date as the table below shows.

Table showing military regimes \& their policies and programmes in Nigeria.

\begin{tabular}{|c|l|l|}
\hline No & Socio-economic developmental policies \& programmes & Regime \\
\hline 1. & Creation of 12 states in 1967 & Gowon regime \\
\hline 2. & Creation of 19 states in 1976 & Murtala/Obasanjo regime \\
\hline 3. & Creation of 21 states in 1987 & Babangida regime \\
\hline 4. & Creation of 30 states in 1991 & Babangida regime \\
\hline 5. & Creation of 36 states in 1996 & Abacha regime \\
\hline 6. & $\begin{array}{l}\text { The execution of second National Development Plan 1977-74 and the Third National Development } \\
\text { Plan 1975-80 }\end{array}$ & $\begin{array}{l}\text { Gowon regime \& Murtala/Obasan } \\
\text { jo regime }\end{array}$ \\
\hline 7. & Enhancement of agricultural development through operation feed the Nation (OFN) & Murtala/Obasanjo regime \\
\hline 8. & Back to Land scheme & Buhari regime \\
\hline 9. & National Census conducted in 1973 & Gowon regime \\
\hline 10. & National Census Conducted in 1991 & Babangida regime \\
\hline 11. & Initiation and implementation of indigenization. Decres of 1971 & Gowon regime \\
\hline 12. & Nigeria Enterprises Promotion Decree of 1978 & Obasanjo regime \\
\hline 13. & National Accelerated Food Production Programme and Nigerian Agricultural \& Cooperative Bank to & Gowon regime \\
\hline 14. & Fund Agricultural Based Economy 1972 & \\
\hline 15. & Peoples Bank of Nigeria and Community Bank of Nigeria & Babangida regime \\
\hline 16. & Better Life Programme (BLP) for rural women empowerment & Babangida regime \\
\hline 17. & The Family Support Programme (FSP) of 1993 & Babangida regime \\
\hline 18. & Family Economic Advancement Programme (FEAP) OF 1993 & Abacha regime \\
\hline 19. & The National Directorate of Employment (NDE) of 1986 & Abacha regime \\
\hline 20. & Structural Adjustment Programme (SAP) & Babangida regime \\
\hline 21. & The Nomadic and Adult Education Programme (NALPA) of 1986 & Babangida regime \\
\hline 22. & The introduction of the National Youth Service Corp (NYSC) of 1973 & Babangida regime \\
\hline 23. & 1976 Local Government Reforms & Gowon regime \\
\hline 24. & 1988 Local Government Reforms & Murtala/Obasanjo \\
\hline 25. & Local Government reforms of 1991 & Babangida regime \\
\hline 26. & War Against Indiscipline (WAl) & Babangida regime \\
\hline 27. & The minimum wage reform for Civil Servants 1998 & Buhari regime \\
\hline
\end{tabular}

Sources: Eminue (2002), and Eshikena (2012) 
From the table above, we can deduce that past military regimes in Nigeria have initiated one programme or the other, with immense impact on the socio-economic development of the country.

Nonetheless, the recurring poor state of the economy in terms of socio-economic development of Nigeria, shows that the policies and programmes of successive military regimes have not really transformed the economy thereby, having little or no impact on the socio-economic development of Nigeria.

Ekele (2011) argues however, that the stunted level of socio-economic development of Nigeria is caused by the corrupt and lack of accountability of military regimes. In the same vein, Eminue (2006) and Edie (2003), believes the military appropriate more funds to itself indiscriminately during their reign in power than necessary. They are said to expend more on non-productive ventures than on productive ones, with negative effects on the socio-economic development of the country. Furthermore, the scholars observed that the rapidly growing oil revenues that coincided with the reign of military regimes were blatantly squandered and mismanaged than channeled towards the socio-economic development of the country.

Eminue (2003) further argued that the military even worsen the socio-economic development of the country by strangulating the nation's true federal structure as evident prior to 1966. As he aptly sum it up:

"governance by the military dealt a fundamental damage to Nigeria federalism, from which it has remain a shell of itself. The uniquely distinctive characteristics of the federal system of government has since disappeared" (Eminue; 2006;67)

It is obvious that successive military regimes in Nigeria have made little or no significant impact on the socioeconomic development of the country due to their inherent characteristics as an aberration in governance.

\section{The Military and Socio-Economic Development in Nigeria: Issues and Problems}

Eminue (2006), Ekele (2011) and Ake (1981) observed that the socio-economic improvement of nations is often the yardstick for measuring the performance of any government. Hence, when people aspire for or assume power, they often state their policies and programmes that are aimed at transforming the socio-economic prospects of their countries. The same can be said of military regimes in Nigeria's history. Successive regimes have often used the prevailing state of socio-economic development as one of their justifications for intervening in politics.

As usual, the regimes often pledges to improve the socio-economic development of the country. It should however be noted that the strategies employed to achieve such objectives varies from regime to regime.

A common trend of the socio-economic policies initiated by military regimes in Nigeria is the need to boost agriculture, alleviate poverty and reform the economy. In agreement with the above view, Eminue (2006) observed that Nigerian military regimes had implemented several programmes, yet there was the preponderance of economic decline as evident in poverty among the masses, spiraling inflation, growing unemployment, policy summersault and economic stagnation.

There was also the depletion of the nation's foreign reserves, reduction in real income, declining Gross Domestic products, wide spread corruption among public servants and lastly, slow pace of infrastructural development.

The above scenario actually compounded and made the socio-economic programmes of successive military regimes to be less impactful on the socio-economic development of Nigeria, inspite of the enormous revenues accruing to the country from crude oil during the military misadventure.

\section{Conclusion}

Successive military regimes in Nigeria have remained an aberration of governance. Though, they have tried to engineer socio-economic development with several policies and programmes, they have barely created appreciable impact on the socio-economic development of Nigeria.

It should be noted that since successive military regimes could not properly address the socio-economic development of the country as promised at the onset of intervention, it is appropriate for the military to remain in the Barracks and perform their constitutional role(s) and help sustain the democratic development and nation building of Nigeria rather than intervene in politics.

\section{Recommendations}

There is the need to thoroughly professionalize the military to depoliticize the military so as to make them more functional 
and effective.

There is also the need for increased budgetary allocation to the military so as to sustain their professional role

The welfare of the rank and file of the officers should be adequately taken care of so that they can have a sense of belonging and can concentrate on their traditional or constitutional roles.

The civilian administration should imbibe the culture of good governance so that the military would not have any excuse to overthrow civilian government.

\section{References}

Adesina, R. A. (1999), Military in Politics: Comprehensive Strategies for Ending Military Rule in Africa Nigeria: Heinemann Educational Books.

Ake, C. (1981) A Political Economy of Africa. London: Addison - Wesley Longman Ltd.

Awofeso, O. (2002). "The Military and Politics in Nigeria" Unpublished Monograph.

Elaigwu, J. I. (1979). "The Military and State Building: Federal State Relations in Nigeria's Military Federalism" (1996 - 1976) in Akinyemi, A. B. et al (eds). Readings on Federalism. Lagos: NIIA.

Eminue, O. (2006). Military in Politics. Uyo: Soulmate Press and Publishers.

Eshikena, J. (2012). Nigerian Government and Politics. Lagos: Fortran Press Ltd.

Edie, C. J. (2003). Politics in Africa: A New Beginning. Belmont: Wadsworth/Thomason Learning.

Ekele, S. (2011). Issues and Problems of Military and Politics in Africa. Nairobi: Musuve Publishing Company.

Finer, S. (1981). The Man on Horseback: the Role of the Military in Politics. London: Pall Mall Press.

Janowitz, M. (1964). The Military in the Political Development of New Nations: An Essay in Comprehensive Analysis. Chicago: University of Chicago Press.

Joseph, R. (1991). Democracy and Prebendal Politics in Nigeria: the Rise and Fall of the Second Republic. Ibadan: Spectrum Books Ltd.

Karl, D. W. (1961) "Social Mobilization and Political Development" in Finkle, J. and Gable3, R. (eds). Political Development and Social change American Political Science Review 55. September. 634-47.

Mazrui, A. A. (1975). Soldiers and Kinsmen in Uganda. Berveley Hills: Sage Publications.

Oyediran, Oyeleye (ed) (1996) Governance and Development in Nigeria: Essays in Honour of professor Bily J. Dudley, Ibadan: Oyediran consult international.

WiseGeek (2014) "Socio-economic Development" in www.wisegeek.com 